\title{
Antioxidant activity tests on novel triterpenoids from Salvia macrochlamys
}

\author{
Gülaçtı Topçu ${ }^{a}$, Abdülselam Ertaş ${ }^{b}$ Ufuk Kolak ${ }^{b}$, Mehmet Öztürk, ${ }^{b, c}$ and \\ Ayhan Ulubelen ${ }^{b^{*}}$ \\ ${ }^{a}$ Department of Chemistry, Faculty of Science and Letters, Istanbul Technical University, 34469 \\ Maslak, Istanbul, Turkey \\ ${ }^{*}$ Faculty of Pharmacy, Istanbul University, 34116 Beyazit, Istanbul, Turkey \\ ${ }^{c}$ Department of Chemistry, Faculty of Science and Arts, Muğla University, 48000 Muğla, Turkey \\ E-mail: aulubelen@yahoo.com
}

\section{Dedicated to Prof. Dr. Atta-ur-Rahman to mark his 65th birthday and to acknowledge his hundreds of articles and many books in the field of phytochemistry}

\begin{abstract}
The methanol extract of Salvia macrochlamys Boiss. and Kotschy was fractionated on a silica gel column to yield a group of terpenic compounds. After separation and cleaning, seven known and three new terpenoid compounds were isolated, and their structures were elucidated by spectroscopic methods, including intensive NMR and MS studies. The crude extract was tested in five different systems for antioxidant activity. The extract and monogynol A (1) and its three derivatives (2-4) were found to be highly active in a metal chelating test system on ferrous ions.
\end{abstract}

Keywords: Salvia macrochlamys, Labiatae, terpenoids, antioxidant activity

\section{Introduction}

Salvia species have been used in folk medicine since ancient times to cure tuberculosis, ${ }^{1,2}$ cancer, ${ }^{3}$ diabetes, ${ }^{4}$ coronary heart diseases, angina pectoris and myocardial infarction. ${ }^{5,6}$ Skin diseases such as psoriasis and eczama ${ }^{7}$ could be treated by Salvia species and they also exhibit oestrogenic activities. ${ }^{8}$ In Turkey there are about 90 Salvia species, half of them being endemic, and some species are consumed as tea, especially in rural areas. ${ }^{9}$ Our group has studied over 50 Salvia species for their chemical contents and their biological activities.

From the whole plant, after extraction and chromatographic separation seven known and three new terpenoids were isolated. The known compounds were germanicol, germanicol acetate, ${ }^{10}$ lupeol, lupeol acetate, ${ }^{11}$ monogynol A, ${ }^{12,13}$ ursolic acid ${ }^{14}$ and caryophyllene oxide. ${ }^{15}$ 
The three new compounds were monogynol A (1) derivatives 3 $\beta$-acetylmonogynol A (2), $3 \beta$-acetyl,22 $\beta$-hydroxymonogynol A (3), 3 $\beta$-acetyl,21 $\beta, 22 \beta$-dihydroxymonogynol A (4) (Fig.1). Their structures were determined by using spectral data including intensive 1D and 2D NMR techniques (DEPT, COSY, HMQC, HMBC and NOESY).

\section{Results and Discussion}

The structure of the first new compound was established as $3 \beta$-acetylmonogynol A (2) on the basis of spectral data. Although it was prepared from monogynol A previously, ${ }^{16}$ this is the first time that it was isolated from nature.

The HRMS spectrum of compound 2 exhibited a molecular ion peak at $\mathrm{m} / \mathrm{z} 486.4100$ corresponding to the molecular formula $\mathrm{C}_{32} \mathrm{H}_{54} \mathrm{O}_{3}$. This indicated the presence of six degrees of unsaturation, of which five were accounted for by a pentacylic ring system and one by an acetoxy group carbonyl. The ${ }^{13} \mathrm{C}$ NMR spectrum having 9 methyl, 10 methylene, 6 methine and 7 quaternary carbons correlated with the given structure for 2 . In the ${ }^{1} \mathrm{H}$ NMR spectrum of the compound 2, eight methyl signals were observed at $\delta 0.83,0.84,0.85,0.87,1.00,1.06,1.24$, 1.35 as singlets. The main difference between monogynol A (1) and compound 2 was in the chemical shift of $\mathrm{H}-3$ which was observed more downfield resonating at $\delta 4.49(1 \mathrm{H}, \mathrm{dd}, J=5.8$ and $10.5 \mathrm{~Hz}$ ) versus to $\delta 3.20$ in lit. ${ }^{16}$ The acetyl group was observed in ${ }^{1} \mathrm{H}$ NMR spectrum at $\delta$ 2.04 and $\delta 21.59$ for methyl and $\delta 171.30$ for carbonyl in the ${ }^{13} \mathrm{C} N M R$ spectrum. Its IR spectrum verified the presence of the acetyl group with the bands at 1725 and $1260 \mathrm{~cm}^{-1}$. Finally monogynol A (1) obtained in this study was acetylated in the usual way and compared with compound 2 on a TLC plate, and both were found to be identical, ${ }^{16}$ their ${ }^{1} \mathrm{H}$ NMR and IR data were also found to be exactly the same.

The structure of the second new compound was deduced as 3 $\beta$-acetyl,22 $\beta$ hydroxymonogynol A (3). The HRMS of compound 3 exhibited a molecular ion at $\mathrm{m} / z 502.4075$ corresponding to the molecular formula $\mathrm{C}_{32} \mathrm{H}_{54} \mathrm{O}_{4}$ with six double-bond equivalents, of which five were accounted for by a pentacyclic ring system skeleton and one by carbonyl of the acetoxy group. Spectral properties of ${ }^{1} \mathrm{H}$ and ${ }^{13} \mathrm{C}$ NMR were quite similar to those of compound 2 , with the exception of additional methine proton at $\delta 3.53$ as a double doublet. Its location was ascertained through a HMBC experiment and ${ }^{13} \mathrm{C}$ NMR shift values of the methyl signals. In the APT and HSQC experiments no meaningful chemical shift difference was observed for the A, $\mathrm{B}, \mathrm{C}$ and $\mathrm{D}$ ring protons and carbons compared to compound 2; therefore, the second hydroxyl group should probably be at ring E, also C-18 ( $\delta 45.68)$ and $\mathrm{C}-19(\delta 47.51)$ on ring $\mathrm{E}$ were resonated almost at the same frequencies with those of compound 2 . Both $\mathrm{C}-18$ and $\mathrm{C}-19$ atoms showed HMBC correlation (Fig. 2) with methyl protons at $\delta 0.82$ which was assigned to Me-28. The most indicative information was obtained by the observation of a three-bond away correlations between protons of Me-28 and C-22 ( $\delta$ 79.55), and protons of Me-28 and C-16 $(\delta$ 33.47 ) which unambiguosly indicated the location of the second hydroxyl group to be at C-22. 
The HSQC and HMBC experiments also allowed us to determine the methyl groups at $\delta 0.94$ and 1.07 must belong to Me-27 and Me-26, respectively, particularly by the observation of twoand three-bond away correlations between both methyl protons with C-8 $(\delta 41.60)$ and C-14 $(\delta$ $43.74)$ in the latter experiment. In addition, methyl protons at $\delta 0.85$ and 0.87 showed three-bond away correlations with the carbon at $\delta 55.5$ (C-5) which led to their assignments as C-23 and C25 methyls, respectively. The stereochemistry of the hydroxyl group at $\mathrm{C}-22$ was deduced as $\beta$, by studying on a Dreiding model, and from the $J$ value of the peak at $\delta 3.53$ (dd, $J=7.80$ and $9.75 \mathrm{~Hz}$ ) which was verified by a NOESY experiment following from NOESY correlations between H-22 and H-18. Thus, the structure of compound 3 was determined as $3 \beta$-acetyl,22 $\beta$ hydroxymonogynol A based on mass and intensive NMR spectral data including ${ }^{1} \mathrm{H}$, APT, HSQC, HMBC and NOESY experiments.

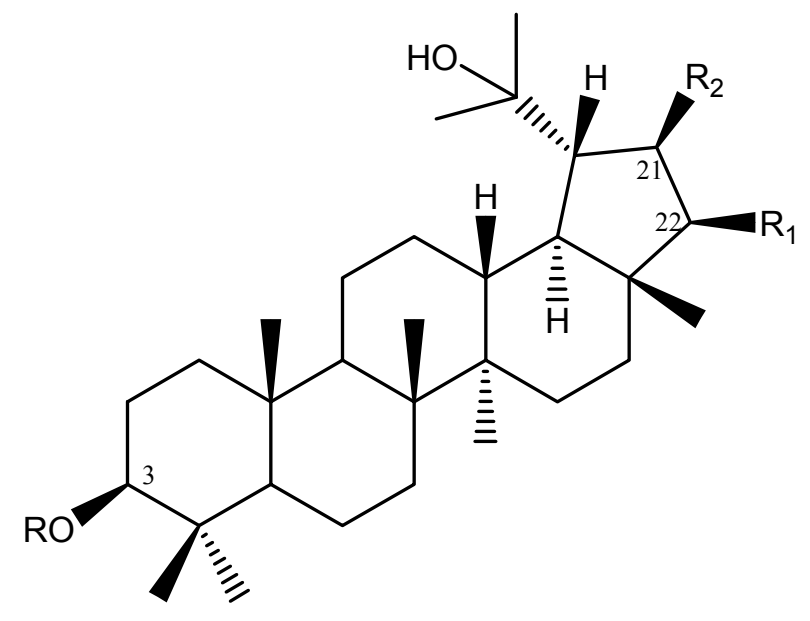
(1) Monogynol A
$\mathrm{R}=\mathrm{H} \quad \mathrm{R}_{1}=\mathrm{H} \quad \mathrm{R}_{2}=\mathrm{H}$
(2) $3 \beta$-Acetylmonogynol A
$\mathrm{R}=\mathrm{Ac} \quad \mathrm{R}_{1}=\mathrm{H} \quad \mathrm{R}_{2}=\mathrm{H}$
(3) $3 \beta$-Acetyl,22 $\beta$-hydroxymonogynol A
$\mathrm{R}=\mathrm{Ac} \mathrm{R}_{1}=\mathrm{OH} \mathrm{R}_{2}=\mathrm{H}$
(4) $3 \beta$-Acetyl,21 $\beta, 22 \beta$-dihydroxymonogynol A R $=A c R_{1}=O H \quad R_{2}=O H$

Figure 1. Chemical formulae of the compounds 1-4. 
Table 1. ${ }^{1} \mathrm{H}$ and ${ }^{13} \mathrm{C}$ NMR data of compounds $\mathbf{2}, \mathbf{3}$ and $\mathbf{4}$ (in $\mathrm{CDCl}_{3}, J$ values in parantheses as $\mathrm{Hz}$ )

\begin{tabular}{|c|c|c|c|c|c|c|}
\hline $\mathrm{C}$ & ${ }^{1} \mathrm{H}(2)$ & ${ }^{1} \mathrm{H}(\mathbf{3})$ & ${ }^{1} \mathrm{H} \quad$ (4) & ${ }^{13} \mathrm{C}(2)$ & ${ }^{13} \mathrm{C}(3)$ & ${ }^{13} \mathrm{C}(4)$ \\
\hline 1 & $0.97 \mathrm{~m} ; 1.74 \mathrm{~m}$ & $0.99 \mathrm{~m} ; 1.70 \mathrm{~m}$ & $1.00 \mathrm{~m} ; 1.71 \mathrm{~m}$ & 38.03 & 38.61 & 38.68 \\
\hline 2 & $\begin{array}{l}1.66 \text { dddd }(3,4 \text {, } \\
12,13)\end{array}$ & $1.61 \mathrm{~m}$ & $1.60 \mathrm{~m} ; 1.90 \mathrm{~m}$ & 23.91 & 23.91 & 23.89 \\
\hline 3 & $\begin{array}{l}4.49 \mathrm{dd} \\
(5.8,10.5) \\
\end{array}$ & $\begin{array}{l}4.48 \mathrm{dd} \\
(6.0,10.6)\end{array}$ & $\begin{array}{l}4.48 \mathrm{dd} \\
(5.9,10.5)\end{array}$ & 81.15 & 81.17 & 81.17 \\
\hline 4 & - & - & - & 38.27 & 38.01 & 38.20 \\
\hline 5 & $0.80 \mathrm{brd}$ & $0.80 \mathrm{brd}$ & $0.78 \mathrm{brd}$ & 55.74 & 55.50 & 55.52 \\
\hline 6 & & & $1.39 \mathrm{~m} ; 1.52 \mathrm{~m}$ & 18.40 & 18.43 & 18.36 \\
\hline 7 & $1.40 \mathrm{~m}$ & $1.41 \mathrm{~m}$ & $1.28 \mathrm{~m} ; 1.60 \mathrm{~m}$ & 35.10 & 34.70 & 34.66 \\
\hline 8 & - & - & - & 41.26 & 41.60 & 42.06 \\
\hline 9 & $1.27 \mathrm{~m}$ & $1.28 \mathrm{~m}$ & $1.28 \mathrm{~m}$ & 50.90 & 50.45 & 50.75 \\
\hline 10 & - & - & - & 37.32 & 37.23 & 37.86 \\
\hline 11 & & & $1.25 \mathrm{~m} ; 1.51 \mathrm{~m}$ & 21.41 & 21.56 & 21.87 \\
\hline 12 & & $1.84 \mathrm{~m}$ & & 26.76 & 27.36 & 27.29 \\
\hline 13 & & $1.67 \mathrm{~m}$ & $1.89 \mathrm{~m}$ & 37.23 & 37.16 & 36.95 \\
\hline 14 & - & - & - & 42.83 & 43.74 & 44.81 \\
\hline 15 & & $1.27 \mathrm{~m}$ & $1.26 \mathrm{~m} ; 1.38 \mathrm{~m}$ & 29.61 & 29.56 & 29.22 \\
\hline 16 & & & & 33.96 & 33.47 & 33.69 \\
\hline 17 & - & - & - & 42.21 & 46.63 & 41.69 \\
\hline 18 & $1.43 \mathrm{~m}$ & $1.42 \mathrm{~m}$ & $\begin{array}{l}1.59 \mathrm{dd} \\
(9.6,11.5)\end{array}$ & 45.26 & 45.68 & 45.02 \\
\hline 19 & $\begin{array}{l}1.83 \text { br dd (8.2, } \\
10.5)\end{array}$ & $1.81 \mathrm{~m}$ & $1.93 \mathrm{t}(9.6)$ & 45.26 & 47.51 & 46.22 \\
\hline 20 & - & - & - & 71.40 & 73.17 & 74.79 \\
\hline 21 & & & $4.20 \mathrm{dd}(9.36,9.60)$ & 29.79 & 32.13 & 79.18 \\
\hline 22 & & $3.53 \mathrm{dd}(7.8,9.75)$ & $3.53 \mathrm{~d}(9.36)$ & 41.04 & 79.55 & 84.20 \\
\hline 23 & 0.85 & 0.85 & 0.83 & 28.17 & 28.16 & 28.17 \\
\hline 24 & 0.84 & 0.84 & 0.82 & 16.74 & 16.72 & 16.72 \\
\hline 25 & 0.87 & 0.87 & 0.84 & 16.63 & 16.42 & 16.56 \\
\hline 26 & 1.06 & 1.07 & 1.06 & 16.73 & 16.71 & 16.59 \\
\hline 27 & 1.00 & 0.94 & 0.97 & 15.13 & 15.01 & 15.22 \\
\hline 28 & 0.83 & 0.82 & 0.80 & 14.38 & 12.39 & 13.97 \\
\hline 29 & 1.24 & 1.15 & 1.24 & 26.32 & 25.46 & 29.56 \\
\hline 30 & 1.35 & 1.23 & 1.34 & 28.18 & 31.74 & 32.34 \\
\hline OAc & 2.04 & 2.05 & 2.03 & $\begin{array}{l}21.59 \\
171.30 \\
\end{array}$ & $\begin{array}{l}21.50 \\
171.74 \\
\end{array}$ & $\begin{array}{l}21.50 \\
171.76 \\
\end{array}$ \\
\hline
\end{tabular}


The third new compound was also a derivative of monogynol $\mathrm{A}$ and its structure was deduced as $3 \beta$-acetyl,21 $\beta, 22 \beta$-dihydroxymonogynol A (4) on the basis of spectral data. The HRMS of 4 exhibited a molecular ion peak at $\mathrm{m} / \mathrm{z} 518.3996$ corresponding to the molecular formula $\mathrm{C}_{32} \mathrm{H}_{54} \mathrm{O}_{5}$ which correlated with the ${ }^{13} \mathrm{C}$ NMR findings consisting of 9 methyl, 8 methylene, 8 methine and 7 quaternary carbons. The ${ }^{1} \mathrm{H}$ NMR spectrum of compound 4 showed similar skeleton profile to those of $\mathbf{2}$ and $\mathbf{3}$ with eight methyl signals at $\delta 0.80,0.82,0.83,0.84$, $0.97,1.06,1.24$ and 1.34 as singlets. There were three methine signals which should be adjacent to oxygenated substituents, followed from ${ }^{1} \mathrm{H}$ and ${ }^{13} \mathrm{C}$ NMR spectra at $\delta 4.48(1 \mathrm{H}, \mathrm{dd}, J=5.9$, $10.5 \mathrm{~Hz}), 4.20(1 \mathrm{H}, \mathrm{dd}, J=9.36,9.60 \mathrm{~Hz})$ and $3.53(1 \mathrm{H}, \mathrm{d}, J=9.36 \mathrm{~Hz})$ and corresponding carbons at $\delta 81.17$ (C-3), 79.18 (C-21) and 84.20 (C-22) respectively, determined by HSQC spectrum. Their locations were identified through COSY and HMBC experiments (Fig. 2). The COSY experiment allowed us to observe a COSY correlation between the signals at $\delta 3.53$ and 4.20 indicating that they must be vicinal protons. However, there was no COSY relation between these signals and the signal at $\delta 4.48$ which attached to C-3 proton. This signal gave a COSY correlation with the signal at $\delta 1.60(\mathrm{~m})$ indicating that the latter signal should belong to one of the $\mathrm{C}-2$ protons. The signal at $\delta 1.60$ further gave a COSY correlation with its geminal proton at $\delta 1.90$ as well as the signal at $\delta 1.00$ which is assigned to one of the $\mathrm{C}-1$ protons $(\mathrm{H}-1 \alpha)$. Observation of direct correlations between $\mathrm{C}-1$ signal at $\delta 38.68$ and proton signals at $\delta 1.00$ and $1.71(\mathrm{H}-1 \beta)$ verified that both signals belong to $\mathrm{C}-1$ protons. Since C-5, C-6 and C-7 are resonated at exactly the same ppm with those observed in monogynol $\mathrm{A}$, and there was no interaction in the COSY experiment between the signal at $\delta 4.48(\mathrm{H}-3)$ and the methine protons at $\delta 3.53$ and 4.20 , the latter two protons should take place on other than $\mathrm{A}$ and $\mathrm{B}$ rings by attaching to the oxygenated carbons. On the other hand, these two protons, therefore their adjacent oxygenated substituents could not be located at ring $\mathrm{C}$ or $\mathrm{D}$ because of their multiplicities, the only possible place for them was found to be on ring E. The observation of COSY correlation between the signal at $\delta 4.20 \mathrm{dd}(J=9.36$ and $9.60 \mathrm{~Hz})$ and a triplet signal at $\delta$ 1.93 (H-19) is attributed to their vicinity, and therefore the location of the former signal at C-21 on ring E. A three-bond away correlation between C-19 ( $\delta 46.22)$ with Me-29 and Me-30 ( $\delta 1.24$ and 1.34) were clearly observed, as well as correlation between C-18 with Me-28 $(\delta 0.80)$ by HMBC experiment (Fig. 2). In fact, the location of two secondary hydroxyl groups at C-21 and C-22 were also determined by HMBC experiments following two-, three- and four-bond away correlations. A two-bond away correlation was observed between H-19 with C-21, and a threebond away correlation between proton signal of Me-28 ( $\delta 0.80)$ with C-22 ( $\delta 84.20)$, and fourbond away correlation Me-28 with C-21 ( $\delta$ 79.18) which indicating the location of both secondary hydroxyl groups should be on ring E. Since their vicinity, both H-21 and H-22 showed a two-bond away HMBC correlation with each other carbons. Two-bond correlations were further observed between C-20 signal at $\delta 74.79$ with two methyl singlets at $\delta 1.24$ and 1.34. Assignments of the all methyl groups were made based on their HSQC and HMBC correlations (Fig.2). Three-bond away correlations were observed between C-3 ( $\delta$ 81.17) with the methyl signals at $\delta 0.82$ and 0.83 , which allowed the assignments of the latter signals to Me-24 and Me- 
23, respectively. The stereochemistry of the hydroxyl groups located at C-21 and C-22 were deduced from their $J$ values and by studying on a Dreiding model as well as by NOESY experiments. Thus, both methine protons, attached to the secondary hydroxyl groups on ring E, showed a NOESY correlation with each other, as well as with H-18, while no correlation was observed between them with either $\mathrm{H}-19$ or Me-28 protons.

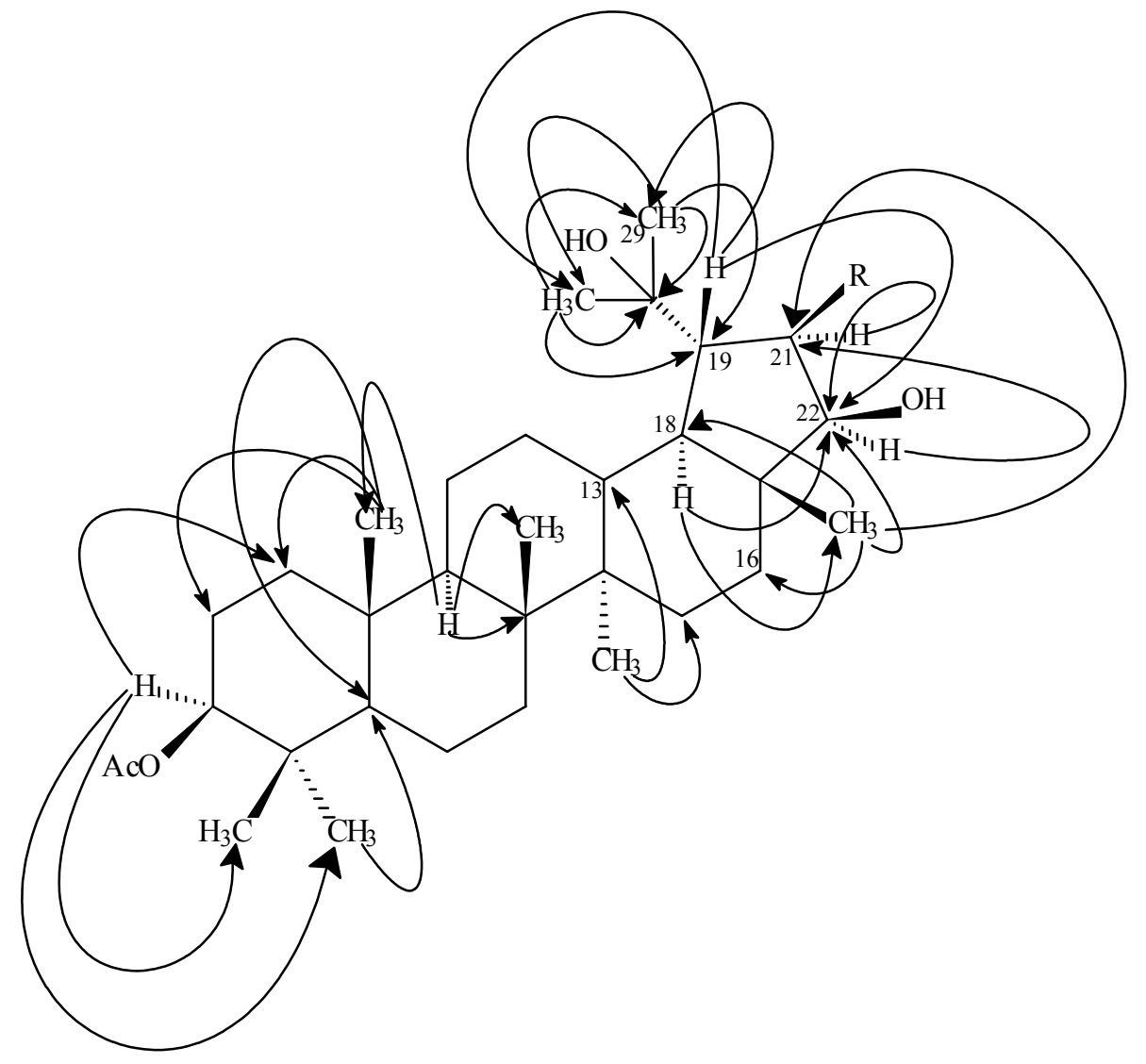

Figure 2. HMBC correlation of compounds 3 and 4.

The mass fragmentation patterns of all three new compounds (2-4) followed by APCI (atomic pressure-chemical ionization) technique and they are shown in Figure 3 giving the main fragments $(\underline{a}),(\underline{b}),(\underline{c})$ and $(\underline{d})$ which are characteristic for lupane ring by the cleavage of ring $\mathrm{C}$ at the ring junctions. ${ }^{17}$ 


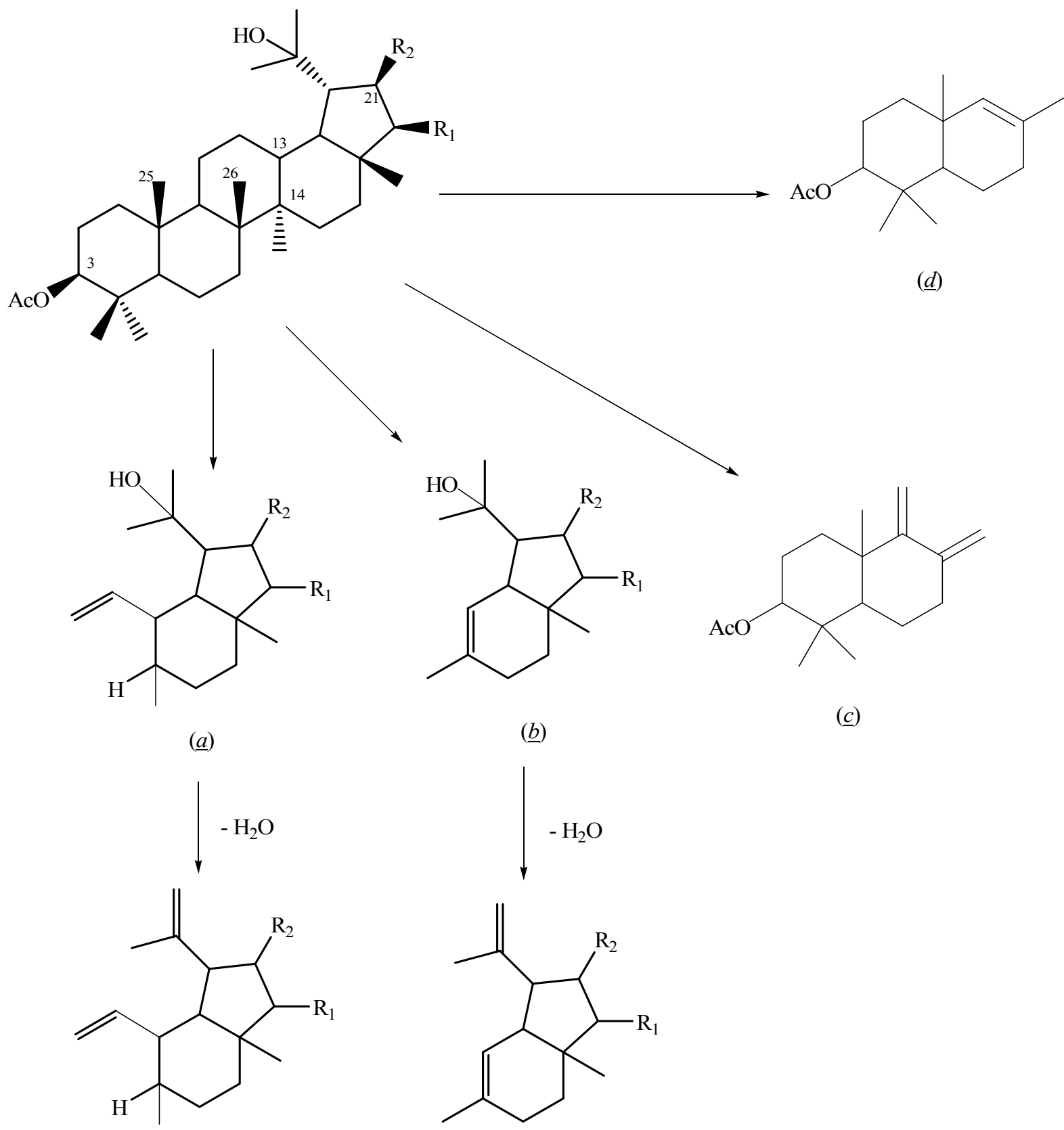

Figure 3. The mass fragment patterns of the three new compounds 2-4.

The extract of Salvia macrochlamys was tested in five different methods for potential antioxidant activity consisting of free radical scavenging activity by DPPH (Table 2), antioxidant activity by $\beta$-caroten-linoleic acid (Fig. 4), superoxide anion radical scavenging activity (Fig.5) in PMS-NADH system, CUPRAC test for $\mathrm{Cu}$ (II) reducing capacity (Fig. 6), and metal chelating activity with ferrozine (Fig. 7). While the extract was not found to be active in the DPPH test system it showed moderate activity, in general (Table 2). Particularly, in inhibition of superoxide anion radical generation, the extract showed better activity than standard BHT and a similar 
activity to that of ascorbic acid at $12.5-25 \mu \mathrm{g} / \mathrm{mL}$ concentrations, while in inhibition of lipid peroxidation it exhibited less activity, however, there was a linearity with increasing concentration, and inhibition was observed to be the same with that of BHT at $50 \mu \mathrm{g} / \mathrm{mL}$ concentration.

Table 2. DPPH radical scavenging activity (inhibition \%) of S. macrochlamys extract and triterpenes (1-4) $)^{\mathrm{a}}$

\begin{tabular}{lrrr}
\hline \multicolumn{1}{c}{ Sample } & \multicolumn{1}{c}{$25 \mu \mathrm{g}$} & \multicolumn{1}{c}{$50 \mu \mathrm{g}$} & \multicolumn{1}{c}{$100 \mu \mathrm{g}$} \\
\hline Extract & $5.33 \pm 0.55$ & $12.67 \pm 0.26$ & $19.81 \pm 0.76$ \\
$\mathbf{1}$ & $0.24 \pm 0.05$ & $0.61 \pm 0.01$ & $1.06 \pm 0.00$ \\
$\mathbf{2}$ & $0.36 \pm 0.07$ & $0.93 \pm 0.03$ & $1.50 \pm 0.00$ \\
$\mathbf{3}$ & $0.88 \pm 0.00$ & $1.50 \pm 0.03$ & $2.59 \pm 0.03$ \\
$\mathbf{4}$ & $0.41 \pm 0.00$ & $0.88 \pm 0.04$ & $1.37 \pm 0.03$ \\
Q-Tocopherol $^{\mathrm{b}}$ & $92.66 \pm 0.07$ & $93.28 \pm 0.07$ & $93.40 \pm 0.99$ \\
BHT $^{\mathrm{b}}$ & $38.98 \pm 0.34$ & $57.48 \pm 0.01$ & $78.27 \pm 0.63$ \\
\hline
\end{tabular}

${ }^{a}$ Values expressed are means \pm S.D. of three parallel measurements. $(\mathrm{P}<0.01)^{\mathrm{b}}$ Reference compounds.

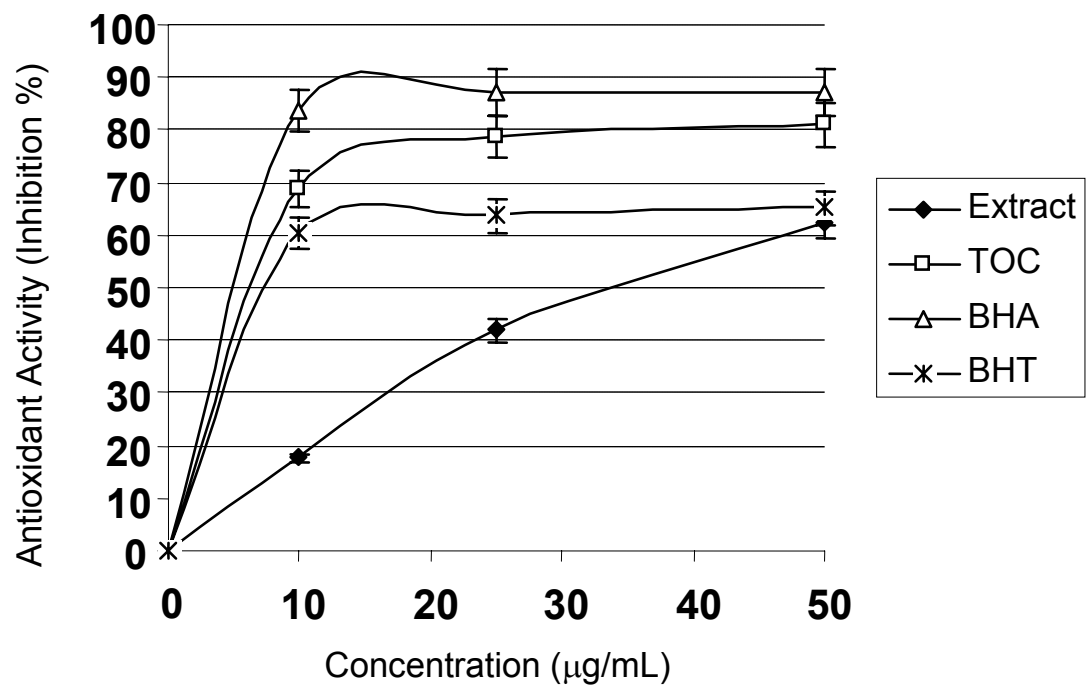

Figure 4. Inhibition (\%) of lipid peroxidation of S. macrochlamys extract, BHT, BHA and TOC, by the $\beta$-carotene bleaching method (BHT: butylated hydroxytoluene; BHA: butylated hydroxyanisole; TOC: $\alpha$-tocopherol).

It is noteworthy that the plant extract showed high activity in metal chelating system giving better results than those of tested standards TOC, BHT and quercetin (Fig. 7). Therefore, 
isolated monogynol A (1) and its new derivatives (2-4) were investigated in the same test system for their metal chelating activity, and they were found not as active as the crude extract, however, they showed comparible activity results with those of the standards (Fig. 7).

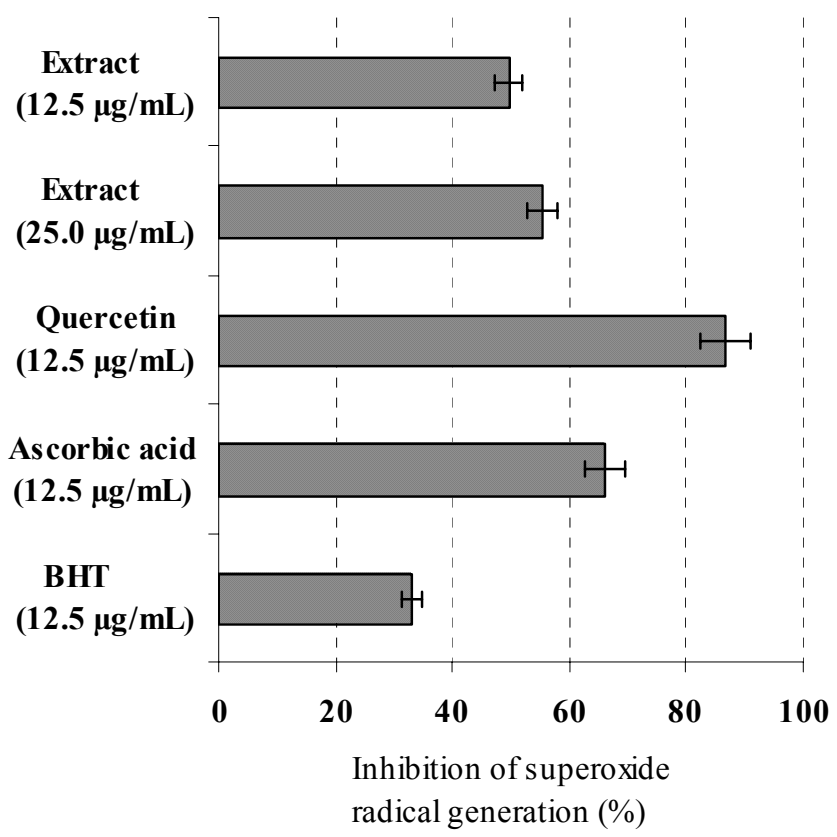

Figure 5. Superoxide anion radical scavenging activity of $S$. macrochlamys extract at 12.5 and $25.0 \mu \mathrm{g} / \mathrm{mL}$ concentrations.

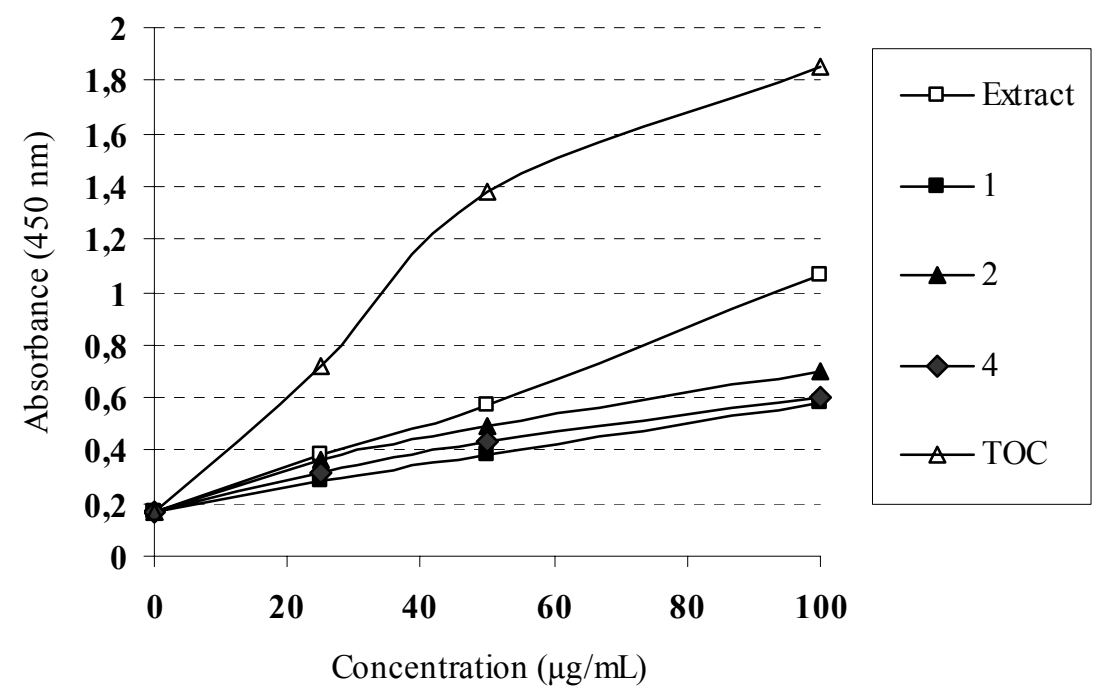

Figure 6. Cupric reducing antioxidant capacity (CUPRAC) of different concentrations of the extract and triterpenes $(\mathbf{1 - 2}, 4)$ comparing with $\alpha$-tocopherol using spectrophotometric detection of the $\mathrm{Cu}^{+2}-\mathrm{Cu}^{+1}$ transformation. 


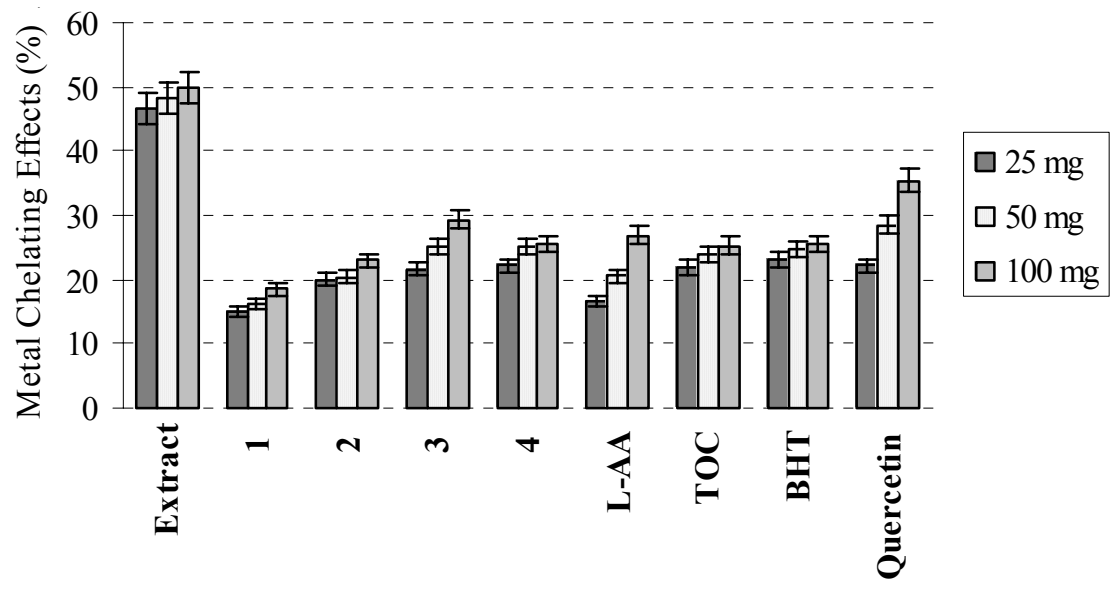

Figure 7. Metal chelating effect of different concentrations of the extract and triterpenes (1-4) on ferrous ions.

\section{Experimental Section}

General Procedures. IR spectra were recorded on Perkin-Elmer in $\mathrm{CHCl}_{3} ;{ }^{1} \mathrm{H}$ and ${ }^{13} \mathrm{C}$ NMR on a Varian Mercury-Vx $400 \mathrm{NMR}$ spectrometer operating at $400 \mathrm{MHz}$ for ${ }^{1} \mathrm{H}$ - and at $100 \mathrm{MHz}$ for ${ }^{13} \mathrm{C}$ NMR in $\mathrm{CDCl}_{3}$ (TMS as an internal standard) (at Boğaziçi University), HRMS were recorded on VG-ZabSpec (Micromass) and APCI on Thermo Deca XP-MAX instrument. All UV-vis measurements were recorded on a Shimadzu UV-1601 (Kyoto, Japan). Ferric chloride, chloroform, methanol, L-ascorbic acid (L-AA), quercetin and copper (II) chloride were obtained from E. Merck (Darmstadt, Germany). $\beta$-carotene, linoleic acid, polyoxyethylene sorbitan monopalmitate (Tween-40), 1,1-diphenyl-2-picrylhydrazyl (DPPH), butylated hydroxytoluene (BHT), butylated hydroxyanisole (BHA) and $\alpha$-tocopherol (TOC), 3-(2-pyridyl)-5,6-bis(4phenyl-sulphonicacid)-1,2,4-triazine (Ferrozine), nicotinamide adenine dinucleotide (NADH), neocuproine and ammonium acetate were obtained from Sigma Chemical Co. (Sigma-Aldrich GmbH, Sternheim, Germany). Nitrotetrazolium blue chloride (NBT) and N-methylphenazonium methyl sulphate (PMS) were obtained from Fluka Chemie (Fluka Chemie GmbH, SigmaAldrich, Sternheim, Germany). Kieselgel 60F 254 (E. Merck) TLC plates were used for preparative separation of the compounds, and silica gel (E. Merck) for column chromatography.

Plant Material. The whole plant Salvia macrochlamys Boiss. and Kotschy (Labiatae = Lamiaceae family) was collected from eastern Turkey, Bitlis (Alacabük Dağı) in an altitude 2100 m. The plant was collected and identified by Dr. Fevzi Özgökçe (Van, 100. Yıl University), a voucher specimen is deposited in the Herbarium of the Faculty of Sciences and Literature, Department of Botany, Van, F12939. 
Extraction and Isolation. Dried and powdered plant material (275 g) was extracted with $\mathrm{MeOH}$ in a Soxhlet apparatus and dried under a vacuum (25.6 g), a crude residue was obtained. The residue was re-extracted with $\mathrm{CHCl}_{3}$ and dried $(15 \mathrm{~g})$, which was fractioned in a silica gel column $(2.5 \times 100 \mathrm{~cm})$ eluting with petroleum ether $\left(40-60^{\circ}\right)$ followed by a gradient of $\mathrm{CH}_{2} \mathrm{Cl}_{2}$ up to $100 \%$ a gradient of acetone and $\mathrm{MeOH}$ both up to $100 \%$. The fractions obtained from this column were controlled on TLC plates, and similar ones were combined. By preparative TLC plates the following compounds were isolated from Frac. 32-36 germanicol acetate (9 $\mathrm{mg})$, lupeol acetate $(11 \mathrm{mg})$, from Frac.37-39 lupeol (13 mg), germanicol (8 mg), caryophyllene oxide (12 mg), from Frac. 48-51 monogynol A (1) (4.5 mg), from Frac. 62-65 ursolic acid (23 mg), 3 $\beta$ acetylmonogynol A (2) (13.5 mg) and 3 $\beta$-acetyl,22 $\beta$-hydroxymonogynol A (3) (15mg), and from

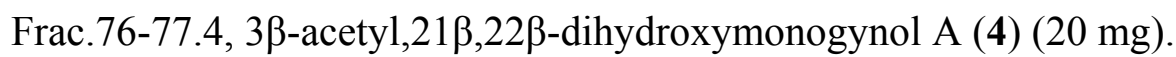

\section{Compound characterization}

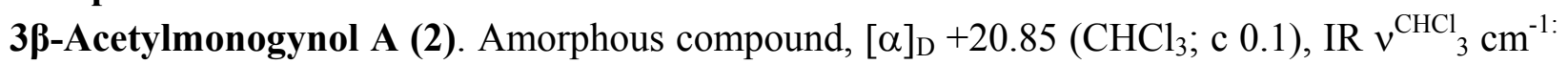
3350, 2960, 2900, 2885, 1722, 1360, 1265, 1170, 1135, 1050, 925, 740. ${ }^{1} \mathrm{H}$ and ${ }^{13} \mathrm{C}$ NMR given

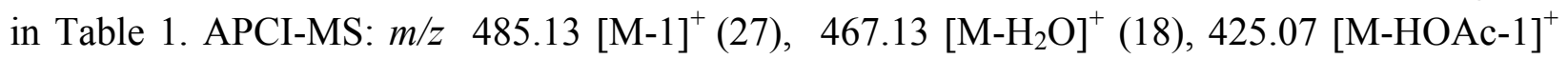
(100) (base peak), $407.27(15), 248.93[(\underline{d})-\mathrm{H}]^{+}(17), 236.13(\underline{a})^{+}(4), 234.93[(\underline{a})-\mathrm{H}]^{+}(13)$, $219.07[(\underline{c})-\mathrm{Ac}-1]^{+}(20), 217.07\left[(\underline{a})-\mathrm{H}_{2} \mathrm{O}-1\right]^{+}(20), 191.07[(\underline{b})-\mathrm{OH}]^{+}$(20) (See Figure 3). HRMS Calcd. $\mathrm{C}_{32} \mathrm{H}_{54} \mathrm{O}_{2}$ : 486.4075. Found: 486.4100 .

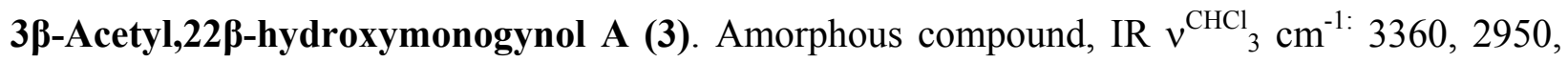
2900, 2880, 1725, 1360, 1265, 1170, 1135, 1050, 925, 740. ${ }^{1} \mathrm{H}$ and ${ }^{13} \mathrm{C}$ NMR are given in Table 1. APCI-MS: $m / z \quad 502.10[\mathrm{M}]^{+}$(49), $483.14\left[\mathrm{M}-\mathrm{H}_{2} \mathrm{O}-1\right]^{+}(20), 465.18\left[\mathrm{M}-2 \mathrm{xH}_{2} \mathrm{O}-1\right]^{+}$(25),

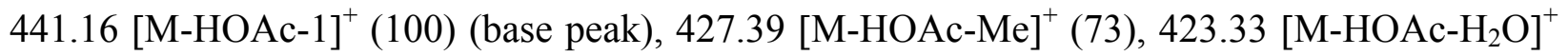
(20), 367.38 [M-HOAc-Me-C $\left.{ }_{3} \mathrm{H}_{7} \mathrm{O}-1\right]^{+}(12), 251.22[(\underline{a})-1]^{+}(8), 234.33\left[(\underline{a})-\mathrm{H}_{2} \mathrm{O}\right]^{+}(8), 224.38$ $[\underline{b}]^{+}(5), 220.15[(\underline{c})-\mathrm{Ac}]^{+}(2), 216.01\left[234-\mathrm{H}_{2} \mathrm{O}\right]^{+}(6), 206.13\left[(\underline{b})-\mathrm{H}_{2} \mathrm{O}\right]^{+}(5), 191.15[(\underline{d})-\mathrm{Ac}$ $+\mathrm{H}^{+}$(13) (See Figure 3). HRMS: Calcd. $\mathrm{C}_{32} \mathrm{H}_{54} \mathrm{O}_{3}: 502.4022$. Found: 502.4075.

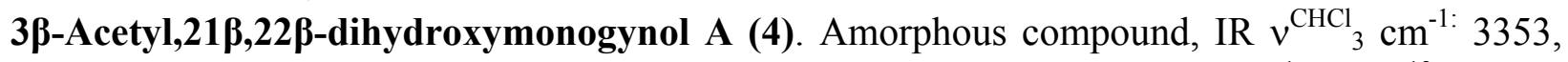
2960, 2910, 2880, 1725, 1720, 1360, 1265, 1260,1170, 1130, 1050, 922, 740. ${ }^{1} \mathrm{H}$ and ${ }^{13} \mathrm{C}$ NMR

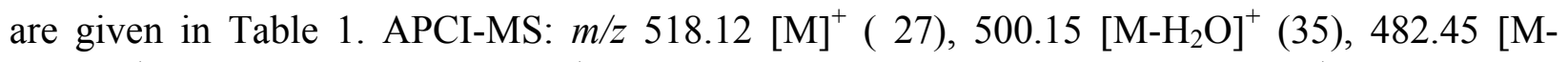
$\left.2 \mathrm{xH}_{2} \mathrm{O}\right]^{+}(17), 458.17$ [M-HOAc] $^{+}$(100)( base peak), 443.12 [M-HOAc-Me] ${ }^{+}$(65), 425.17 $\left[443.12-\mathrm{H}_{2} \mathrm{O}\right]^{+}(17), 268.25[\underline{a}]^{+}(21), 262.35[\underline{c}]^{+}(11), 251.22[(\underline{d})+\mathrm{H}]^{+}(7), 240.21[\underline{b}]^{+}(16)$, 233.39 (27), $222.39\left[(\underline{b})-\mathrm{H}_{2} \mathrm{O}\right]^{+}(15), 208.28[(\underline{d})-\mathrm{Ac}]^{+}(17), 202.41[(\underline{c})-\mathrm{HOAc}]^{+}$(See Figure 3). HRMS: Calcd. $\mathrm{C}_{32} \mathrm{H}_{54} \mathrm{O}_{4}$ : 518.3971. Found: 518.3996.

\section{Acetylation of Monogynol A}

$5 \mathrm{mg}$ of monogynol A (1) was dissolved in pyridine, then $1 \mathrm{~mL}\left(\mathrm{CH}_{3} \mathrm{COO}\right)_{2} \mathrm{O}$ was added and left at room temperature over night. Subsequently diluted with $\mathrm{EtOH}$ and evaporated under vacuum and compared with compound $\mathbf{2}$ on TLC.

\section{Antioxidant Activity Tests}

\section{Determination of the antioxidant activity with the $\beta$-carotene bleaching method}

The antioxidant activity of $S$. macrochlamys extract was evaluated by $\beta$-carotene-linoleic acid model system. ${ }^{18,19} \beta$-carotene $(0.5 \mathrm{mg})$ in $1 \mathrm{~mL}$ of chloroform was added to $25 \mu \mathrm{L}$ of linoleic 
acid, and $200 \mathrm{mg}$ of Tween 40 emulsifier mixture. After evaporation of chloroform under vacuum, $100 \mathrm{~mL}$ of distilled water saturated with oxygen, were added by vigorous shaking. Four thousand microliters of this mixture were transferred into different test tubes containing different concentrations of the sample. As soon as the emulsion was added to each tube, the zero time absorbance was measured at $470 \mathrm{~nm}$ using a spectrophotometer. The emulsion system was incubated for $2 \mathrm{~h}$ at $50^{\circ} \mathrm{C}$. A blank, devoid of $\beta$-carotene, was prepared for background subtraction. BHT and $\alpha$-tocopherol were used as standards (Fig. 4).

\section{Free radical scavenging activity}

The free radical scavenging activity of $S$. macrochlamys extract and triterpenes (1-4) was determined by the DPPH assay described by Blois. ${ }^{20}$ In its radical form, DPPH absorbs at 517 $\mathrm{nm}$, but upon reduction by an antioxidant or a radical species its absorption decreases. Briefly, $0.1 \mathrm{mM}$ solution of DPPH in methanol was prepared, and $4 \mathrm{~mL}$ of this solution was added to 1 $\mathrm{mL}$ of sample solution in methanol at different concentrations. 30 minutes later, the absorbance was measured at $517 \mathrm{~nm}$. Lower absorbance of the reaction mixture indicates higher free radical scavenging activity (Table 2). The capability to scavenge the DPPH radical was calculated using the following equation. ${ }^{20,21}$

DPPH Scavenging Effect $(\%)=\frac{A_{\text {control }}-A_{\text {sample }}}{A_{\text {control }}} \times 100$

\section{Superoxide anion scavenging activity}

Measurement of superoxide anion scavenging activity of $S$. macrochlamys extract was based on the method described by Liu et al. with slight modification. ${ }^{22}$ Superoxide radicals are generated in PMS-NADH systems by oxidation of NADH and assayed by the reduction of NBT. In this experiment, the superoxide radicals were generated in $3 \mathrm{~mL}$ of Tris- $\mathrm{HCl}$ buffer $(16 \mathrm{mM}, \mathrm{pH} \mathrm{8.0})$ containing $1 \mathrm{~mL}$ of NBT $(50 \mu \mathrm{M})$ solution, $1 \mathrm{~mL} \mathrm{NADH}(78 \mu \mathrm{M})$ solution and sample solutions. The reaction started by adding $1 \mathrm{~mL}$ of PMS solution $(10 \mu \mathrm{M})$ to the mixture. The reaction mixture was incubated at $25^{\circ} \mathrm{C}$ for $5 \mathrm{~min}$, and the absorbance at $560 \mathrm{~nm}$ was measured against blank samples. Decreased absorbance of the reaction mixture indicates increased superoxide anion scavenging activity. Results were given as percentage inhibition ${ }^{21}$ (Fig. 5).

\section{Cupric reducing antioxidant capacity (CUPRAC)}

The cupric reducing antioxidant capacity of the extract and triterpenes $(\mathbf{1 - 2}, \mathbf{4})$ was determined according to the method of Apak et al. ${ }^{23}$ To a test tube, $1 \mathrm{~mL}$ each of $10 \mathrm{mM} \mathrm{Cu}$ (II), $7.5 \mathrm{mM}$ neocuprine, and $\mathrm{NH}_{4} \mathrm{Ac}$ buffer $(1 \mathrm{M}, \mathrm{pH} 7.0)$ solutions were added. Extract and triterpenes (1-2, 4) at different concentrations were added to the initial mixture so as to make the final volume 4.1 $\mathrm{mL}$. The tubes were stoppered, and after $1 \mathrm{~h}$, the absorbance at $450 \mathrm{~nm}$ was recorded against a reagent blank (Fig. 6).

\section{Metal chelating activity}

The chelating activity of $S$. macrochlamys extract and triterpenes (1-4) on $\mathrm{Fe}^{2+}$ was measured as reported by Decker, \& Welch. ${ }^{24}$ The extract was added to a solution of $2 \mathrm{mM} \mathrm{FeCl}_{2}(0.1 \mathrm{~mL})$. The reaction was initiated by the addition of $5 \mathrm{mM}$ ferrozine $(0.2 \mathrm{~mL})$. The mixture was shaken vigorously and left standing at room temperature for $10 \mathrm{~min}$. After the mixture reached 
equilibrium, the absorbance was determined at $562 \mathrm{~nm}$, results were given as percentage inhibition $^{21}$ (Fig. 7).

\section{Statistical analysis}

Experimental results concerning this study were mean \pm S.D. of two parallel measurements. Analysis of variance was performed by ANOVA procedures. Significant differences between means were determined by student's- $t$ test, $p$ values $<0.05$ were regarded as significant, $p$ values $<0.01$ were regarded as very significant.

\section{Acknowledgements}

One of us (A.U.) thanks the Turkish Academy of Sciences (TUBA) for the partial support of this study. The Istanbul University, Research Fund with the project number BYP-693/18.05.2005 is also acknowledged for the partial support of this work.

\section{References}

1. Dobrynin, V. N.; Kolosov, M. N.; Chernov, B. K.; Derbentsava, N. A. Khim. Prir. Soedin. 1976, 5, 686.

2. Ulubelen, A.; Topçu, G.; Bozok-Johansson, C. J. Nat. Prod. 1997, 60, 1275.

3. Chien, M. K.; Yang, P. C.; Chin, K. C.; Chen, C. H. Yao Hsueh Tung Pao 1980, 15, 1; Chem. Abs. 1981, 94, 145225c.

4. Jimenez, J.; Risco, S.; Ruiz, T.; Zarduelo, T. Planta Med. 1986, 52, 260.

5. Chen, W. Z. Acta Pharm. Sinica 1981, 19, 876.

6. Chang, H. M.; But, P. P. Pharmacology and Applications of Chinese Materia Medica World Science Pub. Co. Singapore; 1986, Vol. 1, p 773; Chem. Abs. 1987, 106, 27798k.

7. Janosik, J. Czech. Pat. 1980, 185; Chem.Abs. 1981, 95, 68027.

8. Hanson, W. I.; Hocking, G. M. Econ. Bot. 1957, 11, 648.

9. Baytop, T. Therapy with Medicinal Plants in Turkey, Istanbul University Pub. No. 3255, Istanbul, 1984, p156.

10. Gonzales, A. G.; Fraga, B. M.; Gonzales, P.; Hernandez, M. G.; Ravelo, A. G. Phytochemistry 1981, 20, 1919.

11. Djerassi, C.; McDonald, R. M.; Lemin, A. J. J. Am. Chem. Soc. 1953, 75, 5940.

12. Chatterji, S. K.; Anand, N. J. Sci. Ind. Res. (India) 1959, 18B, 282; Chem. Abs. 1960, 54, $15432 \mathrm{~h}$.

13. Ulubelen, A.; Topcu, G.; Lotter, H.; Wagner, H.; Eriş, C. Phytochemistry 1994, 36, 413.

14. Boiteau, P.; Pasich, B.; Ratsimamanga, A. R. Les Triterpenoids, Gautheir-Villars : Paris, 1964, p184.

15. Damodaran, N. P.; Dev, S. Tetrahedron 1968, 24, 4113. 
16. Hui, W.-H.; Li, M.-M. Phytochemistry 1977, 16, 111.

17. Budzikiewicz, H.; Djerassi, C.; Williams D. H. Structure Elucidation of Natural Products by Mass Spectrometry, V. II: Steroids, terpenoids, sugars and miscellaneous classes, HoldenDay, Inc.: San Francisco, 1964; p139.

18. Miller, H. M. J. Am. Oil Chem. Soc. 1971, 45, 91.

19. Türkoğlu, A.; Duru, M. E.; Mercan, N.; Kıvrak, İ.; Gezer, K. Food Chem. 2007, 101, 267.

20. Blois, M. S. Nature 1958, 26, 1199.

21. Gülçin, İ.; Oktay, M.; Kireçci, E.; Küfrevioğlu, Ö. İ. Food Chem. 2003, 83, 371.

22. Liu, F.; Ooi, V. E. C.; Chang, S. T. Life Sci. 1997, 60, 763.

23. Apak, R.; Güçlü, K.; Özyürek, M.; Karademir, S. E. J. Agric. Food Chem. 2004, 52, 7970.

24. Decker, E. A.; Welch, B. J. Agric. Food Chem. 1990, 38, 674. 